\title{
AN OVERVIEW OF ASCORBIC ACID BIOCHEMISTRY
}

\author{
ASKORBİK ASİT BIYYOKİMYASINA BİR BAKIȘ
}

\section{Aysun HACIŞEVKİ}

Gazi University, Faculty of Pharmacy, Department of Biochemistry, 06330 Etiler-Ankara, TURKEY

\begin{abstract}
Ascorbic acid (vitamin C) is a water-soluble micronutrient required for multiple biological functions. Ascorbic acid is a cofactor for several enzymes participating in the post-translational hydroxylation of collagen, in the biosynthesis of carnitine, in the conversion of the neurotransmitter dopamine to norepinephrine, in peptide amidation and in tyrosine metabolism. In addition, vitamin $C$ is an important regulator of iron uptake, It reduces ferric $\mathrm{Fe}^{3+}$ to ferrous $\mathrm{Fe}^{2+}$ ions, thus promoting dietary non-haem iron absorption from the gastrointestinal tract, and stabilizes iron-binding proteins. Most animals are able to synthesise vitamin C from glucose, but humans, other primates, guinea pigs and fruit bats lack the last enzyme involved in the synthesis of vitamin $C$ (gulonolactone oxidase) and so require the presence of the vitamin in their diet. Thus the prolonged deprivation of vitamin $C$ generates defects in the post-translational modification of collagen that cause scurvy and eventually death. In addition to its antiscorbutic action, vitamin $C$ is a potent reducing agent and scavenger of free radicals in biological systems.

Key words: Ascorbic acid, Vitamin C, Antioxidant, Oxidative stress

\section{ÖZET}

Askorbik asit, suda çözünen çoklu biyolojik fonksiyonları olan bir mikrobesindir. Kollajen hidroksilasyonu, karnitin biyosentezi, dopaminin norepinefrine çevrimi, peptid amidasyonu ve tirozin metabolizmasına katılan çeşitli enzimler için bir kofaktördür. Ayrıca vitamin C demir alımında önemli bir regülatördür, ferrik demiri ferro formuna redükler ve böylece gastrointestinal sistemden diyet nonhem demir absorbsiyonunu sağlar ve demir bağll proteinleri stabilize eder. Birçok hayvan glukozdan vitamin $C$ sentezleyebilir fakat insanlar, diğer primatlar, kobay ve yarasalarda vitamin $C$ sentezinde gerekli olan
\end{abstract}


gulonolakton oksidaz enzimi eksik olduğundan diyetlerinde bu vitamine gereksinim gösterirler. Nitekim uzun süreli askorbik asit yokluğu kollajenin post-translasyonel modifikasyonunda defekte neden olup skorbüte ve sonunda ölüme yol açabilir. Antiskorbutik etkisine ilaveten vitamin C biyolojik sistemlerde potent bir redükleyici ajan ve serbest radikal temizleyicisidir.

Anahtar kelimeler: Askorbik asit, Vitamin C, Antioksidan, Oksidatif stres

\section{INTRODUCTION}

Ascorbic acid is involved in many physiological functions in living organisms. Its role in the synthesis of collagen in connective tissues is well known (1-4). The absence of wound healing and the failure of fractures to repair are classically recognized features of scurvy. These features are attributable to impaired collagen formation due to lack of vitamin C. Ascorbic acid is a strong reducing agent and readily oxidizes reversibly to dehydroascorbic acid. Studies on the interactions of ascorbic acid with various chemicals and metal ions have indicated that ascorbic acid and its oxidation product dehydroascorbic acid, as well as its intermediate monodehydroascorbic acid free radical, may function as cycling redox couples in reactions involving electron transport and membrane electrochemical potentiation $(5,6)$. Research on the electron transport and redox coupling reactions has been the subject of numerous biochemical studies. For example, ascorbic acid has been shown to participate in many different neurochemical reactions involving electron transport. Neurons are known to use ascorbic acid for many different chemical and enzymatic reactions, including the synthesis of neurotransmitters and hormones (6,7). Studies on the interactions of extracellular ascorbic acid with various plasma membrane proteins suggest that ascorbic acid may function as a neuromodulator (6).

In a variety of other functions, the role of ascorbic acid in cellular metabolism can be accounted for by its reducing properties to protect cellular components from oxidative damage. It acts as a scavenger for oxidizing free radicals and harmful oxygen-derived species, such as the hydroxyl radical, hydrogen peroxide, and singlet oxygen (5-7). Certain biochemical reactions are known to be stimulated by the prooxidant activity of ascorbic acid. The bactericidal and antiviral activity of ascorbic acid in aqueous solution is presumably attributable to its prooxidant properties $(1,5-7)$.

\section{History of ascorbic acid}

At the begining of the twentieth century, the investigations of Holst and Frolich and the concepts of Funk set the stage for resolving the cause of scurvy. In 1907, Axel Holst with the help of Theodor Frolich, both from Norway, reported that the diseases "ship beriberi" (scurvy) and infantile scurvy could be produced experimentally in the guinea pig (6) by feeding a simple diet of 
oats, barley, rye, and wheat. Feeding the guinea pigs fresh apples, fresh potatoes, fresh cabbage, or fresh lemon juice prevented the disease.

The classical ascorbic acid deficiency disease, scurvy, was demonstrated by Lind to be a dietary deficiency resulting from lack of fresh fruit and vegetables (6). Results of a clinical experiment indicated that scorbutic patients recovered from the disease by drinking lemon juice. The history of vitamin $\mathrm{C}$ is associated with the cause, treatment, and prevention of scurvy. The early signs of scurvy include weakness and lassitude. These are followed by swelling of the legs and arms, softening of the gums, hemorrhages from the nose and gums and under the skin, and extensive degeneration of bone and cartilage. Scorbutic patients are highly susceptible to infection. This vitamin C deficiency disease affected many people in ancient Egypt, Greece, and Rome. In the Middle Ages, it was endemic in Northern Europe during winters, when fresh fruits and vegetables were unavailable. It affected long sea voyages by outbreaks when vitamin $\mathrm{C}$ in rations became depleted $(6,8-12)$.

\section{Molecular structure}

L-ascorbic acid is a dibasic acid with an enediol group built into a five membered heterocyclic lactone ring. The chemical and physical properties of ascorbic acid are related to its structure $(2,5,13)$.

The structure of dehydroascorbic acid, the first oxidation product of ascorbic acid (Fig.1), has been analyzed by x-ray crystallography to be a dimer. Electrochemical studies have indicated that ascorbic acid and dehydroascorbic acid form a reversible redox couple.

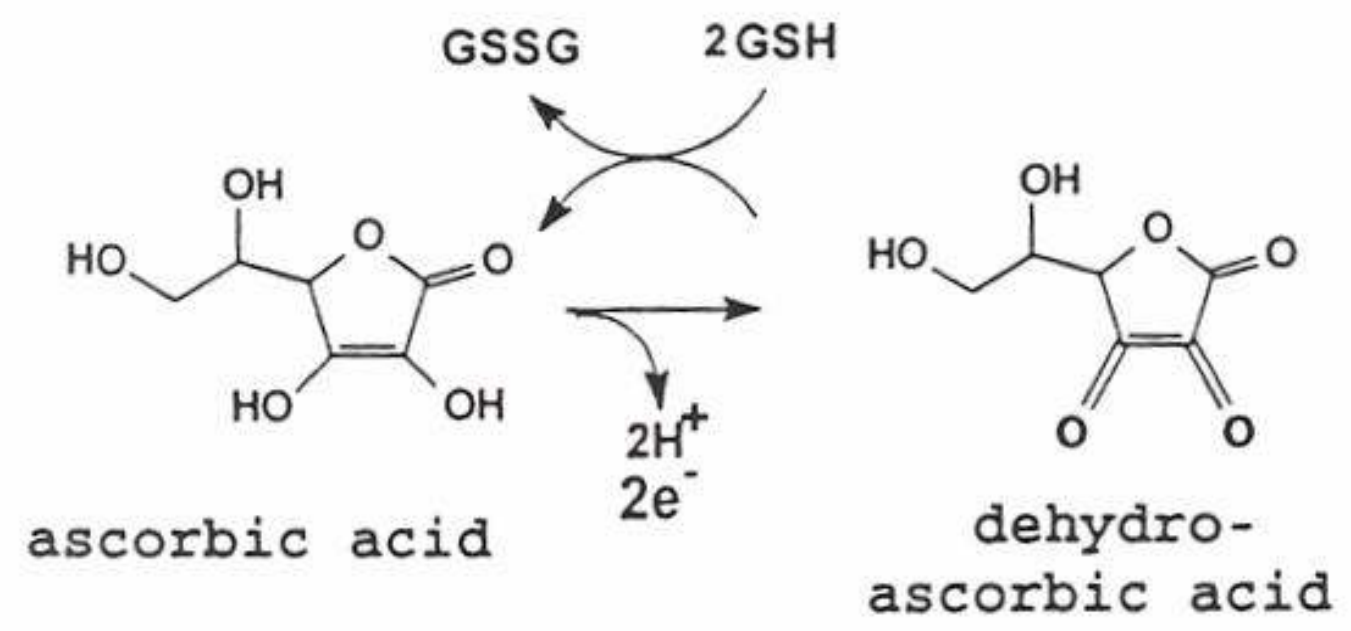

Figure 1. Ascorbic acid and dehydroascorbic acid. Ascorbic acid is the reduced form of vitamin C. The oxidized form, dehydroascorbic acid, can be reduced back to ascorbic acid by glutathione $(\mathrm{GSH})(2,9)$. 
The ascorbic acid molecule consists of two asymmetric carbon atoms, C-4 and C-5 (5). Therefore, in addition to L-ascorbic acid itself, there are three other stereoisomers: D-ascorbic acid, D-isoascorbic acid, and L-isoascorbic acid. These three isomers have very little or no antiscorbutic activity (14-18).

\section{Biosynthesis}

The biosynthesis of ascorbic acid in animals is included in the glucuronic acid metabolic athway. The metabolic pathway is involved in the metabolism of sugars under normal and disease conditions, and in regulation of physiological functions. It is an important pathway for major detoxification processes. The activities of the synthesizing enzymes vary from species to species (1).

Most animals can convert D-glucose into L-ascorbic acid. Humans and other primates, guinea pigs, Indian fruit bats, some fish and birds, and insects are unable to produce ascorbic acid endogenously.

Most of research on ascorbic acid synthesis in animals has been carried out using rats. Dglucose is converted into L-ascorbic acid via D-glucuronic acid, L-gulonic acid, L-gulonolactone and 2-keto-L-gulonolactone as intermediates. Studies with radioactive labeling technique have indicated that, in the synthetic pathway, inversion of C-1 and C-6 takes place between Dglucuronic acid and L-gulonic acid, while the D-glucose chain remains intact.

Animals that cannot synthesize ascorbic acid endogenously lack the oxidizing enzyme Lgulono- $\gamma$-lactone oxidase. This enzyme is required in the last step of the conversion of L-gulono- $\gamma$ lactone to 2-oxo-L-gulono- $\gamma$-lactone, which is a tautomer of L-ascorbic acid and, transforms spontaneously into vitamin C $(19,20)$.

Certain microorganisms are able to synthesize ascorbic acid or one of its isomers. A bacterial-origin enzyme, L-gulono- $\gamma$-lactone dehydrogenase, which catalyzes the oxidation reaction of the synthesis of ascorbic acid, has been isolated and characterized $(5,6)$. The physical and chemical properties of this enzyme are entirely different from those of eucaryotic organisms.

\section{Metabolism}

Ascorbic acid is metabolized in the liver, and to some extent in the kidney, in a series of reactions. The principal pathway of ascorbic acid metabolism involves the loss of two electrons (57). The intermediate free radical reversibly forms dehydroascorbic acid, leading to the irreversible formation of the physiologically inactive 2,3-diketogulonic acid $(21,22)$ Diketogulonic acid may be 
either cleaved to oxalic acid and threonic acid, or decarboxylated to carbon dioxide, xylose, and xylulose, leading eventually to xylonic acid and lyxonic acid. All of these metabolites and ascorbic acid itself fare excreted in the urine (23).

\section{Redox metabolism of ascorbic acid}

In addition to its antiscorbutic action, vitamin $\mathrm{C}$ is a potent reducing agent and scavenger of free radicals in biological systems (24-27). Briefly, mono-anion form (ascorbate) is the predominant chemical species at physiological $\mathrm{pH}$. Ascorbate readily undergoes two consecutive, yet reversible, one-electron oxidations to generate dehydroascorbate (DHA) and an intermediate, the ascorbate free radical (AFR) (Fig.2). AFR is, however, a relatively unreactive free radical, with a reduction potential considerably low compared to the $\alpha$-tocopherol radical, the glutathione radical and virtually all reactive oxygen and nitrogen species that are thought to be involved in human disease (e.g. superoxide anion, hydroxyl radical, hydroperoxyl radicals, singlet oxygen, nitrogen dioxide, nitroxide radicals and hypochlorous acid) $(24,28,29)$.

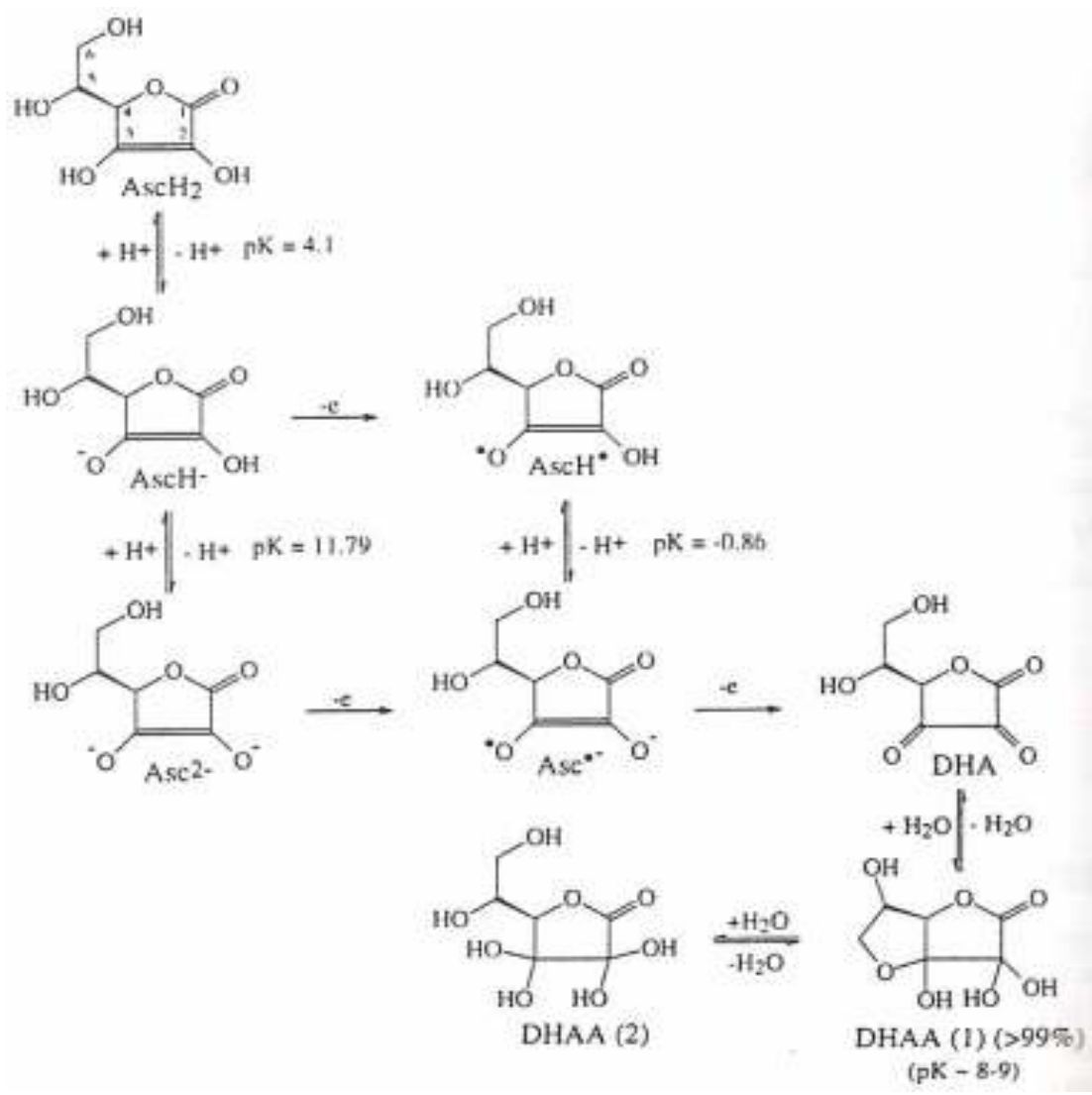

Figure 2.The equilibrium and redox species in the ascorbic acid-dehydroascorbic acid system $(11,24)$ 


\section{Ascorbic acid availability and transport}

Ascorbic acid is water-soluble and is well absorbed from the gastrointestinal tract. Mean plasma ascorbic acid levels are 50-60 $\mu \mathrm{M}$ for healthy, well-nourished, non-smoking individuals (24-30). Plasma levels can be increased by long-term vegetarian diet $(31,32)$ and by oral supplementation up to approximately $100 \mu \mathrm{M} ;(30,33,34)$. Higher plasma levels are not observed even with supplemental doses higher than $500 \mathrm{mg}$ /day due to efficient vitamin C excretion in the urine (35). Some studies have shown that the increase in plasma vitamin $\mathrm{C}$ was accompanied by an increase in the intracellular levels of the vitamin (34); however, this increase is often not dosedependent (24), presumably due to cellular saturation. Thus it is known that the intracellular vitamin C concentrations of neutrophils, monocytes and lymphocytes saturate at lower supplementation doses than human plasma (35).

Cellular vitamin $\mathrm{C}$ transport has been studied in vitro and occurs by two distinct mechanisms $(24,36)$. Ascorbate enters mammalian cells via a family of specific transporters in a process driven by the sodium electrochemical gradient. Absorption of vitamin $\mathrm{C}$ occurs primarily in the distal intestine via active transport through an ascorbate transporter termed the sodium-dependent vitamin C transporter-type 1 (SVCT1, gene product of slc23a1). This transporter is also present in the renal proximal tubules, where it serves to reabsorb filtered ascorbate. Ascorbate circulates in blood at 30$60 \mu \mathrm{M}$, but its concentrations in most cells are considerably higher. This is due to its active transport by another ascorbate transporter isoform, termed the SVCT2 (gene product of slc23a2). The SVCT2 is present in most tissues in the body, including brain, lung, liver, and cardiac and skeletal muscle. Plasma concentrations of ascorbate are limited to about $120 \mu \mathrm{M}$ due to saturation of absorption, uptake into tissues, and failure of complete reabsorption in the kidney (36). Notably, the oxidized form (DHA) is transported into the cells faster than the reduced form by facilitated diffusion through several isoforms of the glucose transporter (GLUT) (37-39), a process that can be inhibited by glucose in some but not all cell types (24).

\section{The roles of ascorbic acid in biological pathways}

Free radicals are produced through biological processes and in response to exogenous stimuli, and controlled by various enzymes and antioxidants in the body. Oxidative stress occurs when free radical formation exceeds the ability to protect against them, what can lead to tissue injury after trauma, inflammatory events and chronic conditions, such as atherosclerosis, degenerative disease and cancer (40). Vitamin E, vitamin $C$, and $\beta$-carotene, often referred to as "antioxidant vitamins", have been suggested to limit oxidative damage in humans, thereby 
lowering the risk of certain chronic diseases. In epidemiological studies, cardiovascular disease is associated with low plasma concentrations of L-ascorbic acid, tocopherol and $\beta$-carotene $(40,41)$.

Ascorbic acid is involved in the metabolism of several amino acids, leading to the formation of hydroxyproline, hydroxylysine, norepinephrine, serotonin, homogenistic acid, and carnitine $(5,42)$. Hydroxyproline and hydroxylysine are components of collagens, the fibrous connective tissue in animals. Collagens are principal components of tendons, ligaments, skin, bone, teeth, cartilage, heart valves, intervertebral disks, cornea, eye lens, and the ground substances between cells. When collagen is synthesized, proline and lysine are hydroxylated posttranslationally on the growing polypeptide chain. Hydroxyproline and hydroxylysine are required for the formation of a stable extracellular matrix and cross-links in the fibers. The subsequent triple helix quaternary state of physiologically effective collagen can only be achieved if the requisite proline and lysine residues have been hydroxylated. A deficiency of ascorbic acid reduces the activity of two mixedfunction oxidases, prolylhydroxylase and lysyl hydroxylase, which hydroxylate proline and lysine. The role of ascorbic acid is probably to maintain the iron cofactor in a reduced state at the active sites of the hydroxylases. Some collagen forms in the absence of ascorbic acid, but the fibers are abnormal, resulting in skin lesions and blood vessel fragility, characteristics of scurvy $(3-5,43,46)$.

L-ascorbic acid can also modulate cell growth and differentiation.L-ascorbic acid reduces or stimulates the growth of tumor cells, depending on the cell type. The inhibitory effect is not specific for the biological active isomer of L-ascorbic acid, and isoascorbate and D-ascorbic acid are more effective in reducing cell growth than L-ascorbic acid (47). L-ascorbic acid and $\alpha$ tocopherol, alone or in combination, induced proliferation and DNA synthesis and also antagonized the anti-proliferative effects of oxLDL in human arterial endothelial cells, whereas the proliferation of VSMC was inhibited (48). Thus, L-ascorbic acid and $\alpha$-tocopherol may act "preventive" on atherosclerotic plaque formation first by promoting re-endothelization and then by inhibition of VSMC proliferation $(41,49)$.

Ascorbic acid regulates and participates in enzymatic reactions and transport for neurotransmitters and in hormone biosynthesis $(43,46)$. In the biosynthesis of a variety of neurochemicals, ascorbic acid is involved in many of the hydroxylation and decarboxylation reactions. Tyrosine is normally catabolized to fumaric and acetoacetic acid via homogenistic acid. Animals deficient in ascorbic acid metabolize tyrosine incompletely. In another metabolic pathway, tyrosine is metabolized in the presence of ascorbic acid to catecholamines by hydroxylation and decarboxylation, forming dopamine, norepinephrine, epinephrine, and adrenocrome. Ascorbic acid is directly involved in the dopamine- $\beta$-hydroxylase reaction to produce norepinephrine. The 
ascorbate free radical may be the primary product of the oxidation. The catecholamine biosynthesis occurs in the adrenal glands and the brain, both with relatively large amounts of ascorbic acid. Ascorbic acid protects catecholamines by direct chemical interactions and by elimination of adrenocrome, a toxic product of catecholamine oxidation, which has been linked to certain mental diseases $(1,3-7)$.

The hydroxylation of tyrosine to catecholamines and the hydroxylation of phenylalanine to tyrosine seem to involve the folic acid derivative tetrahydrobiopterin as an electron carrier, and the recycling of ascorbic acid. Ascorbic acid may function to restore this substrate from the oxidized dihydrobiopterin. It has been suggested that dopamine- $\beta$-hydroxylase works in conjunction with monodehydroascorbate reductase to recycle tetrahydrobiopterin $(6,44)$.

The synthesis of serotonin, a neurotransmitter and vasoconstrictor, involves the hydroxylation and decarboxylation of tryptophan. The initial hydroxylation step, catalyzed by tryptophan hydroxylase, is thought to require ascorbic acid. The cosubstrate for the hydroxylase is tetrahydrobiopterin. Again, it has been suggested that ascorbic acid is able to restore this substrate from its oxidized form, dihydrobiopterin $(1,44)$.

Carnitine is a component of heart and skeletal muscles, liver, and other body tissues. It is essential for the transport of energy-rich activated long-chain fatty acids, from the cytoplasm across the iner mitochondrial membrane to the matrix side, where they are catabolized to acetate. Carnitine is synthesized from lysine and methionine by two hydroxylases through a series of reactions that require ferrous iron and ascorbic acid for full activity (50). A deficiency of vitamin $\mathrm{C}$ can decrease the rate of carnitine biosynthesis, decrease the efficiancy of renal reabsorption of carnitine, and increase urinary carnitine excretion; These effects may account for the acumulation of triglycerides in the blood and the physical fatigue and lassitude in scurvy. (1,3-7,51-53).

Amidation catalyzed by L-ascorbic acid increases the stability and maximal activity of the hormones oxytocin, vasopressin, cholecystokinin and $\alpha$-melanotropin $(41,54-55)$.

$\mathrm{L}$-ascorbic acid reduces $\mathrm{Fe}^{3+}$ to $\mathrm{Fe}^{2+}$ from non-heme iron sources and thus enhances iron absorption (56-57). In the presence of redox-active iron, L-ascorbic acid acts as a pro-oxidant in vitro and might contribute to the formation of hydroxyl radicals, which eventually may lead to lipid, DNA or protein oxidation (58). However, no pro-oxidant effect was observed on L-ascorbic acid supplementation as measured by the amount of DNA damage in presence or absence of iron $(41,59)$. 
Inactivation of the protein phosphatase calcineurin by the superoxide anion, and its protection and reactivation by L-ascorbic acid indicates that reduced iron is required for phosphatase activity, suggesting that vitamin $\mathrm{C}$ may modulate signaling pathways in the cardiovascular system via activation of calcineurin (41, 60-61).

The chemical and biological properties of L-ascorbic acid suggest that it can act as an antioxidant in vivo (62). Lipid peroxidation and oxidative modification of low density lipoproteins (LDL) are implicated in development of atherosclerosis. L-ascorbic acid protects against oxidation of isolated LDL by different types of oxidative stres primarily by scavenging reactive oxygen species in the aqueous milieu (63-64). In studies done in vitro, L-ascorbic acid acted as a synergistic antioxidant together with $\alpha$-tocopherol to prevent LDL oxidation (65). In addition, in vitro studies have shown that physiological concentrations of L-ascorbic acid strongly inhibit LDL oxidation by vascular endothelial cells (66). Adhesion of leucocytes to the endothelium is an important step in initiating atherosclerosis; leucocyte-endothelial cell interactions induced by cigarette smoke or oxidized LDL is inhibited by L-ascorbic acid in vivo (67-69).

Superoxide and oxLDL can lead to endothelial dysfunction by inactivation of nitric oxide (NO), which regulates arterial tone, and inhibits local inflammation, coagulation and cell proliferation (70-71). Oxidative stress and oxLDL impair endothelial function and vasodilatation by reducing nitric oxide bioavailability in the artery wall, events that possibly could be prevented by L-ascorbic acid. However, in a long-term study with vitamin $\mathrm{C}$ and $\mathrm{E}$ supplementation, coronary and brachial endothelial vasomotor function did not improve over six months. Although vitamins $\mathrm{C}$ and $\mathrm{E}$ tended to reduce F2-isoprostanes in this study, they failed to alter oxLDL formation or autoantibodies to oxLDL. Thus, long-term oral vitamins $\mathrm{C}$ and $\mathrm{E}$ did not improve key mechanisms in the biology of atherosclerosis or endothelial dysfunction, or reduce LDL oxidation in vivo (72).

Ascorbate is a primary antioxidant in that it directly neutralizes radical species. Ascorbate is not very reactive with prevalent cellular oxidants such as hydrogen peroxide and probably reacts mostly with hydrogen peroxide breakdown products $(2,73)$.

Ascorbic acid neutralizes superoxide, singlet oxygen and hydroxyl radical (74-78), hypochlorous acid (79) and the iodinating activity of the MPO/H2O2/iodide system (80), but does not scavenge or neutralize $\mathrm{H}_{2} \mathrm{O}_{2}$ per se (81).

\section{Regeneration of vitamin $\mathbf{E}$ by vitamin $\mathrm{C}$}

As long ago as 1941, it was observed that vitamin C increased the antioxidant potency of vitamin $\mathrm{E}$ in lard and cottonseed oil, and in 1968 tappel suggested that vitamin C could regenerate vitamin $\mathrm{E}$ from the vitamin E radical, formed when vitamin E quenches a lipid peroxyl radical (4). 
In 1978, Packer et al (82) confirmed this suggestion. This group found that pulse radiolysis of a solution containing vitamin $\mathrm{E}$ resulted in the formation of a transient species whose absorption spectrum matched that of phenoxyl radicals, which they identified as the vitamin E radical. If vitamin $\mathrm{C}$ was also present, the absorption spectrum after the pulse was initially that of vitamin $\mathrm{E}$, but rapidly converted to that of the vitamin $\mathrm{C}$ radical. Packer et al. further suggested that vitamin $\mathrm{C}$ could be regenerated from its radical form by NADH-dependent processes. Niki et al. also found that vitamin $\mathrm{C}$ regenerated the vitamin $\mathrm{E}$ radical formed by quenching peroxyl radicals generated by oxidation of methyl linoleate in solution (83). In another study the authors note that these results are for vitamin $\mathrm{E}$ and vitamin $\mathrm{C}$ in homogenous solution, whereas in biological systems vitamin $\mathrm{E}$ is found in lipid environments (membranes and lipoproteins) and vitamin $\mathrm{C}$ is found in the aqueous compartment (84).

\section{Regeneration of vitamin C}

In regenerating vitamin $\mathrm{E}$ from its radical form, as well as in scavenging radicals, vitamin $\mathrm{C}$ forms the semidehydroascorbyl radical, a relatively long-lived radical. It has long been known that plant and animal tissues contain a NADH-dependent semidehydroascorbate reductase enzyme (EC 1.6.5.4), which can reduce the radical back to vitamin $\mathrm{C}$ by using NADH as a source of reducing equivalents (Fig 3). This enzyme has been found in microsomal membranes from rat liver (85), as well as in the outer mitochondrial membrane and plasma membrane (86). The semidehydroascorbyl radical decays almost entirely via disproportionation, to ascorbate and dehydroascorbate (the two-electron oxidation product of ascorbate). It can irreversibly decompose to diketogluconic acid, or it can be converted to ascorbate in a glutathione-dependent reaction. The later occurs both enzymatically and nonenzymatically. $(4,87)$

Wells et al. suggest that enzymatic reduction of dehydroascorbate may also be catalyzed by glutaredoxin (thioltransferase) or by protein disulfide isomerase (88). Protein disulfide isomerase is a $57 \mathrm{kD}$ protein found on the lumen side of the endoplasmic reticulum, where it is thought to catalyze rearrangements of disulfide bonds required in native protein folding (89). Mammalian glutaredoxin is a cytosolic enzyme of MW $12 \mathrm{kD}$ that catalyzes the reduction of ribonucleotide (90). Both enzymes have been shown to have significant dehydroascorbate reductase activity (4, $89)$. 


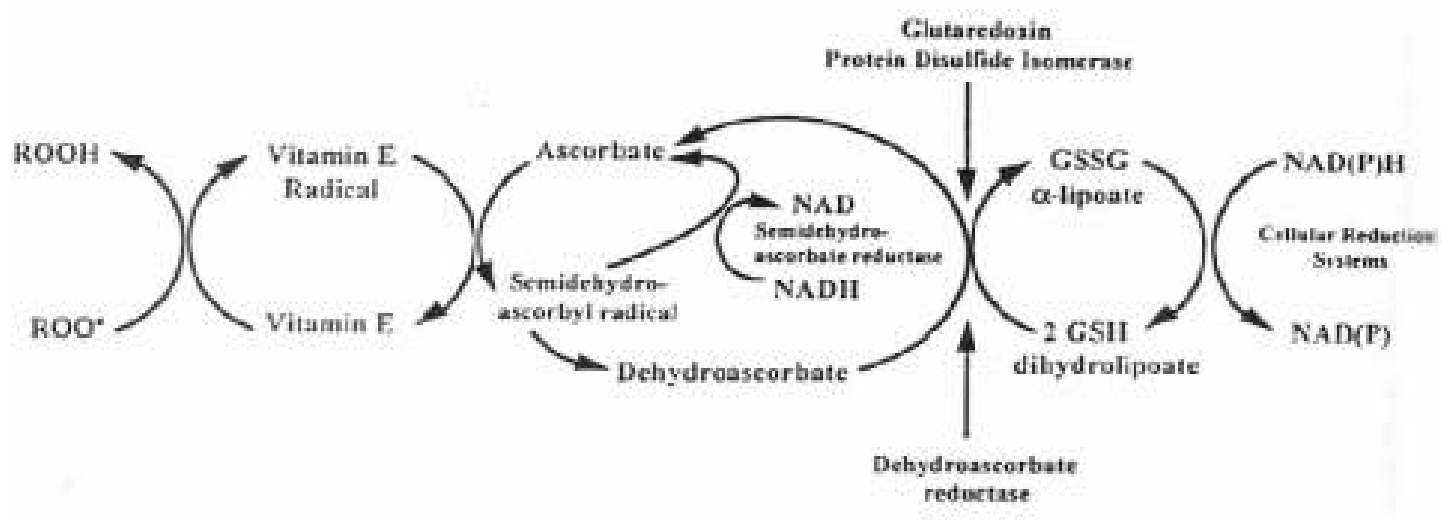

Figure 3. Ascorbate and redox cycling antioxidants. Ascorbate regenerates vitamin E from its radical form, generating the semidehydroascorbyl radical. This radical can be reduced to ascorbate by semidehydroascorbate reductase or disproportionate to dehydroascorbate and ascorbate. Dehydroascorbate can also be reduced to ascorbate by using thiols such as glutathione or dihydrolipoate as a source of reducing equivalents, whose oxidized forms are then reduced by cellular reduction systems utilizing NADPH or NADH. NADPH, reduced nicotinamide-adenine dinucleotide phosphate; NADH, reduced nicotinamideadenine dinucleotide (82).

\section{Pro-oxidant effect of vitamin C}

Paradoxically, ascorbic acid is also known to act as a pro-oxidant in vitro. Mixtures of ascorbic acid and copper or iron have been used for decades to induce oxidative modifications of lipids, proteins and DNA $(24,91)$. Ascorbic acid may contribute to oxidative damage formation by reducing ferric $\mathrm{Fe}^{3+}$ to ferrous $\mathrm{Fe}^{2+}$ ions (and $\mathrm{Cu}^{2+}$ to $\mathrm{Cu}^{+}$), which in turn can reduce hydrogen peroxide $\left(\mathrm{H}_{2} \mathrm{O}_{2}\right)$ to hydroxyl radicals. However, in general these vitamin C-mediated Fenton reactions should be controlled in the human body due to efficient iron sequestration by metal binding proteins such as ferritin and transferrin. Consequently, it has been argued that the prooxidant effect may not be relevant in vivo $(73,92)$. Nevertheless, vitamin $C$ supplements have not been recommended in people with high iron levels or in pathological conditions associated with iron overload such as thalassemia or haemochromatosis (93). Indeed, a mechanism has been provided by which vitamin $\mathrm{C}$ induces the decomposition of lipid hydroperoxydes to genotoxic bifunctional electrophiles in vitro without the need for free transition metal ions $(24,94)$. Paradoxically, in vitro L-ascorbic acid can also promote the generation of reactive oxygen species ( $\mathrm{OH}, \mathrm{O}_{2}^{-}, \mathrm{H}_{2} \mathrm{O}_{2}$, and ferryl ion) in the presence of free $\mathrm{Fe}^{3+}$ or $\mathrm{Cu}^{2+}$. This pro-oxidant activity derives from the ability of $\mathrm{L}$-ascorbic acid to reduce $\mathrm{Fe}^{3+}$ or $\mathrm{Cu}^{2+}$ to $\mathrm{Fe}^{2+}$ or $\mathrm{Cu}^{+}$, respectively, and to reduce $\mathrm{O}_{2}$ to $\mathrm{O}_{2}^{-}$. and $\mathrm{H}_{2} \mathrm{O}_{2}(41,95)$. However, after summarizing the results of in vivo studies that assessed the oxidation of LDL, lipids and proteins, no pro-oxidant activity contributed to Lascorbic acid was evident $(41,92)$. 


\section{Vitamin $\mathrm{C}$ in human disease:}

Low levels of plasma vitamin $\mathrm{C}$ are known to occur in several conditions of increased oxidative stres, such as cancer, diabetes mellitus, cataract, HIV infection, SLE (systemic lupus erythematosus) and smoking habits (96-98). The possible use of vitamin $\mathrm{C}$ in cancer therapy and prevention has been an area of great interest. Thus it is tempting to speculate that vitamin $\mathrm{C}$ supplements, if able to prevent the formation and/or promote the repair of pre-mutagenic oxidative DNA lesions, could be of use in cancer prevention. In addition, an early report showed that daily supplementation with vitamin $\mathrm{C}$ at high doses (grams) increased the survival time of terminal cancer patients (99) and it was suggested that vitamin $\mathrm{C}$ could have important anticancer properties (100). Indeed, vitamin C kills or inhibits the growth of many tumour cell lines (47) and potentiates the cytotoxicity of radiosensitising drugs (101). There are also several reports showing that cancer cell lines are more sensitive to vitamin $C$ than their non-malignant counterparts (102-103). Regarding cancer prevention, several epidemiological studies have linked the consumption of a diet rich in fruit and vegetables (and therefore in antioxidants) with lower incidence of many types of cancer $(24,104-105)$.

In a recent report, Bjekolovic et al. (106) found no evidence that antioxidants can prevent gastrointestinal cancer. On the contrary, certain antioxidant combinations ( $\beta$-carotene with vitamin A or vitamin E) results in increased patient mortality. Vitamin $C$, when added alone or in combination with other antioxidants, did not seem to have an effect on the incidence of gastrointestinal cancers or on overall mortality.

Epidemiological evidence has also associated fruit and vegetable consumption with lower risk of cardiovascular disease (CVD) $(107,108)$. Notably, low plasma levels of vitamin C were associated with death from CVD (109) and it has been speculated in the literature that vitamin C may protect against CVD through several mechanisms.Vitamin C enhances endothelium-dependent vasodilatation, thereby preventing endothelial dysfunction associated with atherosclerosis, hypercholesterolemia, hypertension, diabetes and smoking. This process seem to involve the ability of vitamin $\mathrm{C}$ to increase the atheroprotective nitric oxide (NO) (110). Thus vitamin $\mathrm{C}$ was shown to enhance the activity of endothelial NO synthase by keeping its cofactor, tetrahydrobiopterin, in a reduced state and thereby increasing its intracellular availability $(24,111)$.

\section{Dietary requirement of ascorbate}

There has been much discussion concerning the safety of large doses of ascorbic acid and the amount of vitamin $\mathrm{C}$ that needs to be consumed for optimum well-being (112-115). Various 
authorities have recommended amounts varying from 30 to $10,000 \mathrm{mg} /$ day. In humans a daily consumption of $10 \mathrm{mg}$ of ascorbic acid is usually effective to alleviate and cure clinical signs of scurvy, but this does not necessarily provide an acceptable reserve of the vitamin (116-117).

The RDA for vitamin $\mathrm{C}$ is $60 \mathrm{mg}$ for adult nonsmokers. It is well documented that smokers have lower serum levels of vitamin C. Consequently, in 1989, the RDA of vitamin C for smokers was established as $100 \mathrm{mg}$. From a toxicological standpoint, vitamin $\mathrm{C}$ supplementation is relatively safe, even in megadose levels (i.e., $1-4 \mathrm{~g} / \mathrm{d}$ ) (118).

The current recommended dietary daily allowances for vitamin $\mathrm{C}$ are $90 \mathrm{mg}$ for men and 75 $\mathrm{mg}$ for women. At intakes of the vitamin about $60 \mathrm{mg} / \mathrm{d}$ in both genders, ascorbate begins to appear in the urine. However, intakes of $250 \mathrm{mg} / \mathrm{d}$ and higher are required to saturate ascorbate concentrations in plasma and contents of white blood cells $(2,119)$.

\section{CONCLUSION}

scorbic acid, more commonly known as vitamin $\mathrm{C}$, is widely regarded as an essential antioxidant in the human body and has even been called "the most important antioxidant in human plasma" . Aside from its antioxidant properties, vitamin $\mathrm{C}$ has other important functions, such as the enzymatic function (lysine, proline, and dopamine $\beta$-hydroxylase are examples), hydroxylation of amino acids, and nonenzymatic functions such as increasing gastric iron absorption. As an antioxidant, vitamin $\mathrm{C}$ has two primary actions: First, vitamin $\mathrm{C}$ reacts with and inactivates free radicals in the water-soluble compartments of the body, areas such as the cytosol, plasma, and extracellular fluid. Second, and perhaps equally important, vitamin $\mathrm{C}$ regenerates oxidized vitamin $\mathrm{E}$.

\section{REFERENCES}

1. Chatterjee, I.B., Majunder, A.K., Nandi,B.K., Subramadian, N., "Synthesis and some major functions of vitamin C in animals" Ann.NY Acad.Sci., 258, 24-47 (1975).

2. Aguirre, R., May, J.M., "Inflammation in the vascular bed: Importance of vitamin C" Pharmacol.Ther., 119, 96-103 (2008).

3. Bruick, R.K., McKnight, S.L., "A conserved family of prolyl-4-hydroxylases that modify" Science, 294, 1337-1340 (2001).

4. Myllyla, R., Majamaa, K., Gunzler, V., Hanauske-Abal, H.M., Kivirikko, K.I., "Ascorbate is consumed stoichiometrically in the uncoupled reactions catalyzed by prolyl-4hydroxylase and lysyl hydroxylase" J.Biol.Chem., 259, 5403-5405 (1984). 
5. Tolbert, B.M., Downing, M., Carlson, R.W., et al. "Chemistry and metabolism of ascorbic acid and ascorbate sulfate" Ann. NY Acad. Sci., 258, 48-69 (1975).

6. Packer, L., Fuchs, J., "Vitamin $C$ in health and disease" Marcel Dekker, Inc., New York, Basel, Hong Kong (1997).

7. Arrigoni, O., De Tulio, M.C., "Ascorbic acid: much more than just an antioxidant" Biochim.Biophys.Acta, 1569, 1-9 (2002).

8. Spencer, R.P., Purdy, S., Hoeldtke, R., et al. "Studies on intestinal absorption of Lascorbic acid-1-C14" Gastroenterology, 44, 768-773 (1963).

9. Spencer, R.P., Bow, T.M., "In vitro transport of radiolabeled vitamins by the small intestines" J.Nucl.Med., 5, 251-258 (1964).

10. Stevenson, N.R., "Active transport of L-ascorbic acid in the human ileum" Gastroenterology, 67, 952-956 (1974).

11. Stevenson, N.R., Brush, M.K., "Existence and characteristic of Na+-dependent active transport of ascorbic acid in guinea pig" Am.J.Clin.Nutr., 22, 318-326 (1969).

12. Hornig, D., Weber, F., Wiss, O., "Site of intestinal absorption of ascorbic acid in guinea pigs and rats" Biochem.Biophys.Res.Comm., 52, 168-172 (1973).

13. Buettner, G.R., "The pecking order of free radicals and antioxidants: lipid peroxidation, alpha-tocopherol, and ascorbate" Arch.Biochem.Biophys., 300, 535-543 (1993).

14. Coassin, M., Tomasi, A., Vannini, V., Ursini, F., "Enzymatic recycling of oxidized ascorbate in pig heart: one electron vs two-electron pathway" Arch.Biochem.Biophys., 290, 458-462 (1991).

15. Mehlhorn, R.J., “Ascorbate- and dehydroascorbic acid-mediated reduction of free radicals in the human erythrocyte" J.Biol.Chem., 266, 2724-2731 (1991).

16. Bielski, B.H., Richter, H.W., Chan, P.C., "Some properties of the ascorbate free radical" Ann.NY Acad.Sci., 258, 231-237 (1975).

17. Winkler, B.S., "In vitro oxidation of ascorbic acid and its prevention by GSH" Biochim.Biophys.Acta, 925, 258-264 (1987).

18. Chatterjee, I.B., "Biosynthesis of L-ascorbate in animals" Methods Enzymol., 18, 28-34 (1970). 
19. Nishikimi, M., Fukuyama, R., Minoshima, S., et al. "Cloning and chromosomal mapping of the human nonfunctional gene for L-gulonolactone oxidase, the enzyme for L-ascorbic acid biosynthesis missing in man" J.Biol.Chem., 269, 13685-13688 (1994).

20. Nishikimi, M., Yagi, K., "Molecular basis for the deficiency in humans of gulonolactone oxidase, a key enzyme for ascorbic acid biosynthesis" Am.J.Clin.Nutr., 54, 1203S-1208S (1991).

21. Ashwell, G., Kanfer, J., Smiley, J.D., Burns, J.J., "Metabolism of ascorbic acid and related uronic acids, aldonic acids and pentoses" Ann.NY.Acad.Sci., 92, 105-114 (1961).

22. Fituri, N., Allawi, N., Bentley, M., Costello, J., " Urinary and plasma oxalate during ingestion of pure ascorbic acid: a re-evaluation" Eur.Uro., 9, 312-315 (1983).

23. Kallneri A., Hornig, D., Pellikka, R., "Formation of carbon dioxide from ascorbate in man" Am.J.Clin.Nutr., 41, 609-613 (1985).

24. Duarte, T.L., Lunec, J., "Review:When is an antioxidant not an antioxidant? A review of novel actions and reactions of vitamin C" Free Rad.Res., 39(7), 671-686 (2005).

25. Rose, R.C., Bode, A.M., "Biology of free-radical scavengers-an evaluation of ascorbate" FASEB J., 7, 1135-1142 (1993).

26. Buettner, G.R., Jurkiewicz, B.A., "Catalytic metals, ascorbate and free radicals: Combinations to avoid" Radiat.Res., 145, 532-541 (1996).

27. May, J.M., "Is ascorbic acid an antioxidant for the plasma membrane" FASEB J., 13, 9951006 (1999).

28. May, J.M., Qu, Z.C., Li, X., "Requirement for GSH in recycling of ascorbic acid in endothelial cells" Biochem.Pharmacol., 62, 873-881 (2001).

29. Wilson, J.X., "The physiological role of dehydroascorbic acid" FEBS Lett., 527, 5-9 (2002).

30. Woollard, K.J., Loryman, C.L., Meredith, E., Bevan, R., Shaw, J.A., Lunec, J., Griffiths, H.R., "Effects of oral vitamin C on monocyte: Endothelial call adhesion in healthy subjects" Biochem.Biophys.Res.Cmmun., 294, 1161-1168 (2002).

31. Astley, S.B., Elliott, R.M., Archer, D.B., Southon, S., "Evidence that dietary supplementation with carotenoids and carotenoid-rich foods modulates the DNA damage: Repair balance in human lymphocytes" Br.J.Nutr., 91, 63-72 (2004). 
32. Szeto, Y.T., Kwok, T.C.Y., Benzie, I.F.F., "Effects of a long-term vegeterian diet on biomarkers of antioxidant status and cardiovascular disease risk" Nutrition, 20, 863-866 (2004).

33. Brennan, L.A., Morris, G.M., Wasson, G.R., Hannigan, B.M., Barnett, Y.A., "The effect of vitamin $\mathrm{C}$ or vitamin $\mathrm{E}$ supplementation on basal and $\mathrm{H}_{2} \mathrm{O}_{2}$-induced DNA damage in human lymphocytes" Br.J.Nutr., 84, 195-202 (2000).

34. Choi, S.W., Benzie, I.F.F., Collins, A.R., Hannigan, B.M., Strain, J.J., "Vitamin C and E: Acute interactive effects on biomarkers of antioxidant defense and oxidative stres" Mutat.Res., 551, 109-117 (2004).

35. Levine, M., Conrycantilena, C., Wang, Y.H., Welch, R.W., Washko, P.W., Dhariwal, K.R., Park, J.B., Lazarev, A., Graumlich, J.F., King, J., Cantilena, L.R., "Vitamin C pharmacokinetics in healthy volunteers: Evidence for a recommended dietary allowance" Proc.Natl.Acad.Sci. USA, 93, 3704-3709 (1996).

36. Tsukaguchi, H., Tokui, T., Mackenzie, B., Berger, U.V., Chen, X.Z., Wang, Y.X., Brubaker, R.F., Hediger, M.A., "A family of mammallian Na+-dependent L-ascorbic acid transporters" Nature, 399, 70-75 (1999).

37. Vera, J.C., Rivas, C.I., Fischbarg, J., Golde, D.W., "Mammallian facilitative hexose transporters mediate the transport of dehydroascorbic acid" Nature, 364, 79-82 (1993).

38. Welch, R.W., Wang, Y.H., Crossman, A., Park, J.B., Kirk, K.L., Levine, M., "Accumulation of vitamin C (ascorbate) and its oxidized metabolite dehydroascorbic acid occurs by sperate mechanisms" J.Biol.Chem., 270, 12584-12592 (1995).

39. Rumsey, S.C., Kwon, O., Xu, G.W., Burant, C.F., Simpson, I., Levine, M., "Glucose transporter isoforms Glut 1 and Glut 3 transport dehydroascorbic acid" J.Biol.Chem., 272, 18982-18989 (1997).

40. Ames, B.N., Shigenaga, M.K., Hagen, T.M., "Oxidants, antioxidants, and the degenerative diseases of aging" Proc.Natl.Acad.Sci., USA, 90(17), 7915-7922 (1994).

41. Villacorta, L., Azzi, A., Zingg, J.M., "Regulatory role of vitamins $E$ and C on extracellular matrix components of the vascular system" Molecular Aspects of Med., 28, 507-537 (2007).

42. Barnes, M.J., "Function of ascorbic acid in collagen metabolism" Ann.NY Acad.Sci., 258, 264-277 (1975). 
43. Diliberto, E.J., Daniels, A.J., "Multicompartmental secretion of ascorbate and its dual role in dopamine $\beta$-hydroxylation" Am.J.Clin.Nutr., 54, 1163S-1172S (1991).

44. Eipper, B.A., Mains, R.E., "The role of ascorbate in the biosynthesis of neuroendocrine peptides" Am.J.Clin.Nutr., 54, 1153S-1156S (1991).

45. Tolbert, L.C., Thomas, T.N., Middaugh, L.D., Zemp, J.W., "Effect of ascorbic acid on neurochemical, behavioral, and physiological systems mediated by catecholamines" Life Sci., 25, 2189-2195 (1979).

46. Desole, M.S., Anania, A., Esposito, G., "Neurochemical and behavioral changes induced by ascorbic acid and d-amphetamine in the rat" Pharmacol.Res.Comm., 19, 441-450 (1987).

47. Alcain, F.J., Buron, M.I., "Ascorbate on cell growth and diffrentiation" J.Bioenergy.Biomembr., 26(4), 393-398 (1994).

48. Ulrich-Merzenich, G., Metzner, C., Schiermeyer, B., Vetter, H., "Vitamin c and vitamin E antagonistically modulate human vascular endothelial and smooth muscle cell DNA synthesis and proliferation" Eur.J.Nutr., 41(1), 27-34 (2002).

49. Ivanov, V.O., Ivanova, S.V., Niedzwecki, A., "Ascorbate affects proliferation of guinea-pig vascular smooth muscle cells by direct and extracellular matrix-mediated effects" J.Mol.Cell.Cardiol., 29(12), 3293-3303 (1997).

50. Reboucne, C.J., "Ascorbic acid and carnitine biosynthesis" Am.J.Clin.Nutr., 54, 1147S1152S (1991).

51. Nelson, P.J., Pruit, R.E., Henderson, L.L., "Effect of ascorbic acid deficiency on the in vivo synthesis of carnitine" Biochim.Biophys.Acta, 672, 123-127 (1981).

52. Ha, T.Y., Otsuka, M., Arakawa, N., "the effect of graded doses of ascorbic acid on the tissue carnitine and plasma lipid concentrations" J.Nutr.Sci.Vitaminol., 36, 227-234 (1990).

53. Reboucne, C.J., "Renal handling of carnitine in experimental vitamin C deficiency" Metabolism, 44, 1639-1643 (1995).

54. Cameron, E., Pauling, L., "Ascorbic acid and the glycosaminoglycans. An Orthomolecular approach to cancer and other diseasea" Oncology, 27(2), 181-192 (1973).

55. Naidu, K.A., "Vitamin $C$ in human health and disease is stil a mystery? An overview" Nutr.J., 2(1), 7 (2003). 
56. Goswami, T., Rolfs, A., Hediger, M.A., "Iron transport: emerging roles in health and disease" Biochem.Cell.Biol., 80(5), 679-689 (2002).

57. Teucher, B., Olivares, M., Cori, H., "Enhancers of iron absorption: ascorbic acid and other organic acids" Int.J.Vitam.Nutr.Res., 74(6), 403-419 (2004).

58. Samuni, A., Aronovitch, J., Godinger, D., Chevion, M., Czapski, G., " On the cytotoxicity of vitamin C and metal ions. A site-specific Fenton Mechanism" Eur.J.Biochem., 137(1-2), 119-124 (1983).

59. Proteggente, A.R., Rehman, A., Halliwell, B., Rice-Evans, C.A., "Potential problems of ascorbate and iron supplementation: pro-oxidant effect in vivo?" Biochem.Biophys.Res.Commun., 277(3), 535-540 (2000).

60. Klee, C.B., Ren, H., Wang, X., "Regulation of the calmodulin-stimulated protein phosphatase, calcineurin" J.Biol.Chem., 273(22), 13367-13370 (1998).

61. Wang, X., Culotta, V.C., Klee, C.B., "Superoxide dismutase protects calcineurin from inactivation" Nature, 383(6599), 434-437 (1996).

62. Rose, R.C., Bode, A.M., "Biology of free radical scavengers: an evaluation of ascorbate" FASEB J., 87(12), 1135-1142 (1993).

63. Frei, B., England, L., Ames, B.N., " Ascorbate is an outstanding antioxidant in human blood plasma" Proc.Natl.Acad.Sci., USA, 86(16), 6377-6381 (1989).

64. Jialal, I., Vega, G.L., Grundy, S.M., "Physiologic levels of ascorbate inhibit the oxidative modification of low density lipoprotein" Atherosclerosis, 82(3), 185-191 (1990).

65. Sato, K., Niki, E., Shimasaki, H., "Free radical-mediated chain oxidation of low density lipoprotein and its synergistic inhibition by vitamim $\mathrm{E}$ and vitamin C" Arch.Biochem.Biophys., 279(2), 402-405 (1990).

66. Martin, A., Frei, B., "Both intracellular and extracellular vitamin $\mathrm{C}$ inhibit atherogenic modification of LDL by human vascular endothelial cells" Arterioscler.Thromb.Vasc.Biol., 17(8), 1583-1590 (1997).

67. Lehr, H.A., Frei, B., Arfors, K.E., "Vitramin C prevents cigarette smoke-induced leucocyte aggregation and adhesion to endothelium in vivo" Proc.Natl.Acad.Sci., USA, 91(16), 76887692 (1994). 
68. Lehr, H.A., Frei, B., Olofsson, A.M., Carew, T.E., Arfors, K.E., "Protection from oxidized LDL-induced leucocyte adhesion to microvascular and macrovascular endothelium in vivo by vitamin C but not by vitamin E" Circulation, 91(5), 1525-1532 (1995).

69. Lehr, H.A., Weyrich, A.S., Saetzler, R.K., Jurek, A., Arfors, K.E., Zimmerman, G.A., Prescott, S.M., McIntyre, T.M., "Vitamin C blocks inflammatory platelet-activating factor mimetics created by cigarette smoking” J.Clin.Invest., 99(10), 2358-2364 (1997).

70. Tousoulis, D., Davies, G., TouTouzas, P., "Vitamin C increases nitric oxide availability in coronary atherosclerosis" Ann.Intern.Med., 131(2), 156-157 (1999).

71. TouTouzas, P.C., Tousoulis, D., Davies, G.J., "Nitric oxide synthesis in atherosclerosis" Eur.Heart J., 19(10), 1504-1511 (1998).

72. Kinlay, S., Behrendt, D., Fang, J.C., Delagrange, D., Morrow, I., Witztum, J.L., Rifai, N., Selwyn, A.P., Creager, M.A., Ganz, P., "Long-term effect of combined vitamins E and $\mathrm{C}$ on coronary and peripheral endothelial function " J.Am.Coll.Cardiol., 43(4), 629-634 (2004).

73. Halliwell, B., "Vitamin C: poison, prophylactic or panacea?" Trends.Biochem.Sci., 24, 255259 (1999).,

74. Nishikimi, M., "Oxidation of ascorbic acid with superoxide anion generated by the xanthine-xanthine oxidase system" Biochem.Biophys.Res.Commun., 63, 463-468 (1975).

75. Hemila, H., Roberts, P., Wikstrom, M., "Activated polymorphonuclear leucocytes consume vitamin C" FEBS Lett., 178, 25-30 (1984).

76. Anderson, R., Lukey, P.T., "A biological role for ascorbate in the selective neutralisation of extracellular phagocyte-derived oxidants" Ann.NY Acad.Sci., 498, 229-247 (1987).

77. Bodanes, R.S., Chan, P.C., "Ascorbic acid as a scavenger of singlet oxygen" FEBS Lett., 105, 195-196 (1979).

78. Anderson, R., Theron, A.J., "Physiological potential of ascorbate, $\beta$-carotene and $\alpha$ tocopherol individually and in combination in the prevention of tissue damage, carcinogenesis and immune dysfunction mediated by phagocyte-derived reactive oxidants" World Rev.Nutr.Diet, 62, 27-58 (1990). 
79. Halliwell, B., Wasil, M., Grootveld, M., "Biologically significant scavenging of the myeloperoxidase-derived oxidant hypochlorous acid by ascorbic acid" FEBS Lett., 213, 1518 (1987).

80. Kensler, T.W., Bush, D.M., Kozumbo, W.J., "Inhibition of tumor promotion by a biomimetic superoxide dismutase" Science, 221, 75-77 (1983).

81. McCall, C.E., DeChatelet, L.R., Cooper, M.R., Ashburn, P., "The effects of ascorbic acid on the bacteriocidal mechanisms of neutrophils" J.Infect.Dis., 124, 154-198 (1974).

82. Packer, J.E., Slater, T.F., Wilson, R.L., "Direct observation of a free radical interaction between vitamin E and vitamin c" Nature, 278, 737-738 (1979).

83. Niki, E., Saito, T., Kawakami, A., Kamiya, Y., "Inhibition of oxidation of methyl linoleate in solution by vitamin E and vitamin C"J.Biol.Chem., 259, 4177-4182 (1984).

84. Doba, T.G., Burton, W., Ingold, K.U., "Antioxidant and co-antioxidant activity of vitamin $\mathrm{C}$ : the effect of vitamin $\mathrm{C}$, eitheralone or in the presence of vitamin $\mathrm{E}$ or a water-soluble vitamin $\mathrm{E}$ analogue, upon the peroxidation of aqueous multilamellar phospholipid liposomes" Biochim.Biophys.Acta, 835, 298-303 (1985).

85. Hara, T., Minakami, S., "On functional role of cytochrome b\%.II.NADH-linked ascorbate radical reductase activity in microsomes" J.Biochem., 69, 325-330 (1971).

86. Goldenberg, H.,'Insulin inhibits NADH-semidehydroascorbate reductase in rat liver plasma membrane" Biochim.Biophys.Res.Comm., 94, 721-726 (1980).

87. Winkler, B.S., Orselli, S.M., Rex, T.S., "The redox couple between glutathione and ascorbic acid: a chemical and physiological perspective" Free Rad.Biol.Med., 17, 333-349 (1994).

88. Wells, W.W., Xu, D.P., Yang, Y., Rocque, P.A., "Mammallian thioltransferase(glutaredoxin) and protein disulfide isomerase have dehydroascorbate reductase activity" J.Biol.Chem., 265, 15361-15364 ( 1990).

89. Carmichael, D.F., Morin, J.E., Dixon, J.E., "Purification and characterization of a thiol:protein disulfide oxidoreductase from bovine liver" J.Biol.Chem., 252, 7163-7167 (1977).

90. Luthman, M., Ericksson, S., Holmgren, A., Thelander, L., "Glutathione-dependent hydrogen donor system for calf thymus ribonucleotide diphosphate reductase" Proc.Natl.Acad.Sci., USA, 76, 2158-2162 (1979). 
91. Halliwell, B., Gutteridge, J.M.C., "Free radicals in biology and medicine" Oxford: Oxford University Press, (1999).

92. Carr, A.C., Frei, B., "Does vitamin C act as pro-oxidant under physiological conditions?" FASEB J., 13, 1007-1024 (1999).

93. Herbert, V., Shaw, S., Jayatilleke, E., "Vitamin C-driven free radical generation from iron" J.Nutr., 126, 1213S-1220S (1996).

94. Lee, S.H., Oe, T., Blair, I.A., "Vitamin C-induced decomposition of lipid hydroperoxides to endogenous genotoxins" Science, 292, 2083-2086 (2001).

95. Stadtman, E.R., "Ascorbic acid and oxidative inactivation of proteins" Am.J.Clin.Nutr., 54 (suppl.6), 1125S-1128S (1991).

96. Evans, M.D., Cooke, M.S., Akil, M., Samanta, A., Lunec, J., "Aberrant processing of oxidative DNA damage in systemic lupus erythematosus" Biochem.Biophys.Res.Commun., 273, 894-898 (2000).

97. Jaruga, P., Jaruga, B., Gackowski, D., Olczak, A., Halota, W., Pawlowska, M., Olinski, R., "Supplementation with antioxidant vitamins prevents oxidative modification of DNA in lymphocytes of HIV-infected patients" Free Rad.Biol.Med., 32, 414-420 (2002).

98. Polidori, M.C., Stahl, W., Eichler, O., Niestroj, I., Sies, H., "Profiles of antioxidants in human plasma" Free Rad.Biol.Med., 30, 456-462 (2001).

99. Cameron, E., Pauling, L., "Supplemental ascorbate in the supportive treatment of cancer: Prolongation of survival times in terminal human cancer" Proc.Natl.Acad.Sci., USA, 73, 3685-3689 (1976).

100. Cameron, E., Pauling, L., Leibovitz, B., "Ascorbic acid and cancer: A review" Cancer Res., 39, 663-681 (1979).

101. Koch, C.J., Howell, R.L., Biaglow, J.E., “Ascorbate anion potentiates cytotoxicity of nitroaromatic compounds under hypoxic and anoxic conditions" Br.J.Cancer, 39, 321-329 (1979).

102. Prasad, K.N., Sinha, P.K., Ramanujam, M., Sakamoto, A., "Sodium ascorbate potentiates the growth inhibitory effect of certain agents on neuroblastoma cells in culture" Proc.Natl.Acad.Sci., USA, 76, 829-832 (1979). 
103. Park, C.H., Amare, M., Savin, M.A., Hoogstraten, B., "Growth suppression of human leukemic cells in vitro by L-ascorbic acid" Cancer Res., 40, 1062-1065 (1980).

104. Steinmetz, K.A., Potter, J.D., "Vegetables, fruit, and cancer prevention:A review" J.Am.Diet Assoc., 96, 1027-1039 (1996).

105. Bozkır, A., Şimşek, B., Güngör, A., Torun, M., "Ascorbic acid and uric acid levels in lung cancer patients" J.Clin.Pharm.Therap., 24, $43-47$ (1999).

106. Bjelakovic, G., Nikolova, D., Simonetti, R.G., Gluud, C., "Antioxidant supplements for prevention of gastrointestinal cancers: A systematic review and meta-analysis" Lancet, 364, 1219-1228 (2004).

107. Bazzano, L.A., He, J., Ogden, L.G., Loria, C.M., Vupputuri, S., Myers, L., Whelton, P.K., "Fruit and vegetable intake and risk of cardiovascular disease in US adults: The first national health and nutrition examination survey epidemiologic follow-up study" Am.J.Clin.Nutr., 76, 93-99 (2002).

108. Gonenc, A., Hacışevki, A., Bakkaloglu, B., Soyagir, A., Karagoz, H., Torun, M., Simsek, B., "Oxidative stress is decreased in off-pump vs. on-pump coronary artery surgery" J.Biochem.Mol.Biol., 39(4), 377-382 (2006).

109. Khaw, K.T., Bingham, S., Welch, A., Luben, R., Wareham, N., Oakes, S., Day, N., "Relation between plasma ascorbic acid and mortality in men and women in Epic-Norfolk prospective study: A prospective population study" Lancet, 357, 657-663 (2001).

110. May, J.M., "How does ascorbic acid prevent endothelial dysfunction?" Free Rad.Biol.Med., 28, 1421-1429 (2000).

111. Huang, A., Vita, J.A., Venema, R.C., Keaney, J.F., "Ascorbic acid enhances endothelial nitric oxide synthase activity by increasing intracellular tetrahydrobiopterin" J.Biol.Chem., 275, 17399-17406 (2000).

112. Herbert, V., “Antioxidants, pro-oxidants, and their effects" JAMA, 272, 1659 (1994).

113. Levine, M., Conry-Cantilena, C., Wang, Y., "Vitamin C pharmacokinetics in healthy volunteers: Evidence for a recommended diatary allowance" Proc.Natl.Acad.Sci., USA, 93, 3704-3709 (1996).

114. Levine, M., Dhariwal, K.R., Welch, R.W., "Determination of optimal vitamin C requirements in humans" Am.J.Clin.Nutr., 62, 1347S-1356S (1995). 
115. Gershoff, S.N., "Vitamin C (ascorbic acid): new roles, new requirements?" Nutr.Rev., 51, 313-326 (1993).

116. Harper, A.E., "The recommended dietary allowances for ascorbic acid" Ann.NY Acad.Sci., 258, 491-497 (1975).

117. Kallner, A., "Requirement for vitamin $\mathrm{C}$ based on metabolic studies" Ann.NY Acad.Sci., 498, 418-423 (1987).

118. Rivers, J.M., "Safety of high-level vitamin C ingestion" Int.J.Vitam.Nutr.Res., 30, 95-102 (1989).

119. Levine, M., wang, Y.H., Padayatty, s.J., Morrow, J., "A new recommended dietary allowance of vitamin C for healthy young women" Proc.Natl.Acad.Sci., USA, 98, 98429846 (2001). 